\title{
Nutritional Contribution of Litter in Rainforest of Brazil
}

\author{
Rosival B. A. Lima ${ }^{1}$, Luiz C. Marangon ${ }^{1}$, Fernando J. Freire ${ }^{2}$, Ana L. P. Feliciano ${ }^{1}$, Maria B. G. S. Freire ${ }^{2}$, \\ Roseane K. S. Silva ${ }^{1} \&$ Clarissa S. Freire ${ }^{1}$ \\ ${ }^{1}$ Forestry Sciences Department, Federal Rural University of Pernambuco, Recife, Pernambuco, Brazil \\ ${ }^{2}$ Agronomy Department, Federal Rural University of Pernambuco, Recife, Pernambuco, Brazil \\ Correspondence: Fernando J. Freire, Agronomy Department, Federal Rural University of Pernambuco, Recife, \\ Rua Dom Manoel de Medeiros, CEP 52171-900, Brazil. Tel: 55-81-3320-6223. E-mail: \\ fernandojfreire@uol.com.br
}

Received: October 31, 2018

Accepted: December 2, 2018 Online Published: February 15, 2019

doi:10.5539/jas.v11n3p254

URL: https://doi.org/10.5539/jas.v11n3p254

\begin{abstract}
Lowlands Dense Ombrophilous Forest is one phytophysiognomies of Atlantic Forest in Brazil. The main ecological characteristic of this forest is the Ombrophilous environment, related to high rainfall and temperature indexes. Nutrient cycling is well balanced in the periods of good thermo-pluviometric distribution. Global climatic changes have been intensifying in recent years making rainfall irregular, changing its distribution and intensity throughout the year. This can affect the natural regeneration and vegetative growth of the species. This study aimed to correlate litterfall and nutrient contribution with climatic variations, identifying the level of importance of this correlation and which nutrients may have their compromised cycling. Literfall was collected monthly in 40 collectors. $\mathrm{N}, \mathrm{P}, \mathrm{K}, \mathrm{Ca}$ and $\mathrm{Mg}$ contents were determined and their stocks were calculated. The litter deposition was $8,261.15 \mathrm{~kg} \mathrm{ha}^{-1} \mathrm{year}^{-1}$ and was not influenced by rainfall and temperature. The $\mathrm{N}, \mathrm{P}, \mathrm{K}, \mathrm{Ca}$ and $\mathrm{Mg}$ stock in this litter was $244.93 \mathrm{~kg} \mathrm{ha}^{-1}$ year ${ }^{-1}$, being stored just of $\mathrm{N} 113.75 \mathrm{~kg} \mathrm{ha}^{-1}$ year ${ }^{-1}$. $\mathrm{P}$ and $\mathrm{K}$ stocks varied with rainfall and temperature, suggesting that variations in these climatic variables may interfere in the cycling of these nutrients in this forest fragment.
\end{abstract}

Keywords: nutrient cycling, nutrient supply, forest nutrition, tropical forests

\section{Introduction}

Nutrition of tropical forests is supplied by the stock of nutrients transferred to the soil. The contribution of litter is the main responsible for the entry of nutrients into the forest system (Wood, Lawrence, Clark, \& Chazdon, 2009; Diniz, Machado, Pereira, Balieiro, \& Menezes, 2015).

Litter also acts in light interception, shading of seeds and seedlings, and reducing water evaporation. Additionally, it aids in diminishing the impact of raindrops on soil, which reduces surface runoff and nutrient loss ( $\mathrm{Li}, \mathrm{Niu}, \& \mathrm{Xie}, 2014)$. It is a source of $\mathrm{C}$ and energy for soil organisms, and also considered the most dynamic and probably the most variable fraction not only between ecosystems but also within the same ecosystem (Jacoby, Peukert, Succurro, Koprivova, \& Kopriva, 2017).

The formation of litter layer depends on production and decomposition rate of organic matter that varies according to the substrate composition, decomposers activity, environmental conditions, especially temperature and relative humidity, and physical properties of the soil (Xiaogai et al., 2013).

The contribution of each vegetal material varies depending on the vegetation typology and climatic condition (Banegas, Albanesi, Pedraza, \& Santos, 2015). One way to evaluate this variation is monitoring litter production. Thus, it is possible to comprehend the process of nutrient cycling, to evaluate the productive capacity of the forest, and to relate available nutrients to the nutritional needs of the species. In fact, litter transport is an important bioindicator of climatic variations in forest environments, because it may vary according to air temperature and/or rainfall (Llausás \& Nogué, 2012; Ferreira, Silva, Pereira, \& Lamano-Ferreira, 2014).

The largest litter contribution is due to water deficit in soil, which usually occurs during dry seasons (Silva, Poggiane, Lima, \& Libardi, 2014). When this phenomenon is combined with high air temperatures, forest species are subjected to water stress and loss of plant material (mainly leaves), increasing the supply of litter on the soil. Additionally, since there is little moisture in soil during this period, the decomposition is reduced and 
nutrients accumulate in litter. Leff et al. (2012) found that the contribution of litter was higher in dry seasons and higher air temperatures. The authores also reported that the decomposition occurred faster in times of greater rainfall.

Global climatic changes have been intensified in the past years and Tropical Humid Forests depend of litter to maintain nutrients cycles in balance. This nutritional cycling can vary with rainfall and temperature. If these climatic variations are unbalanced due to global climatic changes, nutrients cycling in these Tropical Humid Forests can be altered and this may compromise the sustainability of this natural ecosystem.

These climatic changes can be interfering with the nutritional balance of Tropical Humid Forest. Both litter deposition and nutrient input may depend on these regular periods of rainfall and temperature. When they are disturbed, they may be providing vegetal material and nutrients though litter in much favorable periods to decomposition, retarding or accelerating the nutrient cycling, and unbalancing the ecosystem. This can affect the natural regeneration of species and both vegetative growth and reproductive cycles of adult trees.

This study aimed to correlate litterfall and nutrient contribution with climatic variations, identifying the level of importance of this correlation and which nutrients may have their compromised cycling.

\section{Method}

\subsection{Study Area}

The study was carried out in a remnant of the Atlantic Forest with 42 ha in the municipality of Sirinhaém, Pernambuco, Brazil. The forest fragment is located in the following geographical coordinates: (UTM 25L) 263220, 263849, 263544 and 263967 of latitude and 9054184, 9054442, 9053691 and 9053725 of longitude (Figure 1). The forest's typology is Lowlands Dense Ombrophilous Forest (L. Martins and Cavararo, 2012). The forest fragment is in middle successional stage. Forests in this region are currently circumvented by extensive sugarcane plantations or by urban areas, reducing the extent of areas with large forests. The studied fragment is a remnant of Atlantic forest that was greatly impacted by anthropic explorations for wood removal, but was regenerated and is currently well preserved.

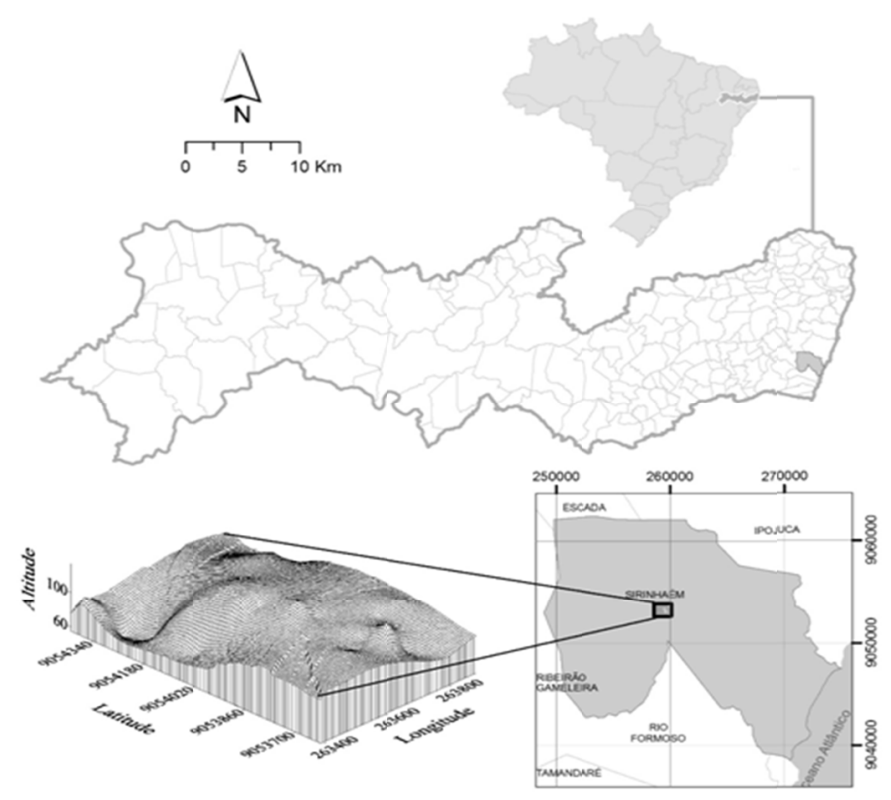

Figure 1. Geographic location of the fragment of Lowlands Dense Ombrophilous Forest, Brazil

The region presents an Am monsoon climate type (Alvares, Stape, Sentelhas, Gonçalves, \& Sparovek, 2013) according to Köppen classification, with an annual average temperature of $25.6{ }^{\circ} \mathrm{C}$. The average altitude is $60 \mathrm{~m}$ and the period of greatest rainfall is from April to September. The average annual rainfall is approximately 1,860 mm (APAC, 2016). 
Air temperature data (minimum, average and maximum) for the period from June 2014 to May 2015 were estimated according to local geographic coordinates: latitude, longitude and altitude, according to Cavalcanti, Silva, and Sousa (2006) (Figure 2).

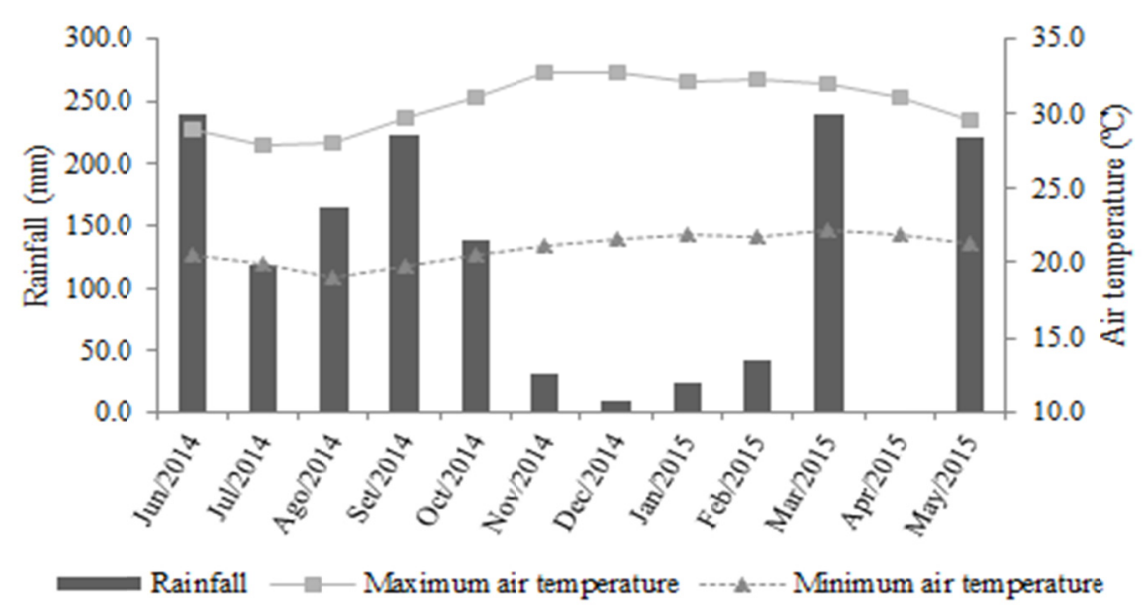

Figure 2. Maximum and minimum air temperatures and rainfall during the monitoring period of litter deposition in the fragment of Lowlands Dense Ombrophilous Forest, Brazil

Source: Cavalcanti et al. (2006) and APAC (2016).

The predominant soils in the region are Yellow Latosol, Yellow Argisol, Red-Yellow Argisol, Gray Argisol and Cambisol (Santos et al., 2013) corresponding to Oxisols, Ultisols and Inceptisols according to USDA Soil Taxonomy (Soil Survey Staff, 2014).

For chemical and physical soil characterization, a systematic sampling was performed in 40 sampling sites. The distance between sampling sites was $35 \mathrm{~m}$. A collection of three simple samples was performed in each site and then they were homogenized, giving rise to a composite sample. Samples were collected at three depths (0.01-0.05, 0.05-0.20 and 0.20-0.40 m) (Table 1). 
Table 1. Chemical and physical characterization of soil in the fragment of Lowlands Dense Ombrophilous Forest, Brazil

\begin{tabular}{llll}
\hline \multirow{2}{*}{ Soil attribute } & \multicolumn{3}{c}{ Depth $(\mathrm{m})$} \\
\cline { 2 - 4 } & $0.0-0.05$ & $0.05-0.20$ & $0.20-0.40$ \\
\hline $\mathrm{pH}\left(\mathrm{H}_{2} \mathrm{O}\right)$ & 3.88 & 4.1 & 4.53 \\
$\mathrm{P}\left(\mathrm{mg} \mathrm{dm}^{-3}\right)$ & 1.37 & 1.3 & 1.1 \\
$\mathrm{Ca}\left(\mathrm{cmol}_{\mathrm{c}} \mathrm{dm}^{-3}\right)$ & 0.3 & 0.12 & 0.05 \\
$\mathrm{Mg}\left(\mathrm{cmol}_{\mathrm{c}} \mathrm{dm}^{-3}\right)$ & 0.83 & 0.46 & 0.4 \\
$\mathrm{~K}\left(\mathrm{cmol}_{\mathrm{c}} \mathrm{dm}^{-3}\right)$ & 0.06 & 0.05 & 0.04 \\
$\mathrm{Al}\left(\mathrm{cmol}_{\mathrm{c}} \mathrm{dm}^{-3}\right)$ & 1.69 & 1.37 & 1.02 \\
$\left(\mathrm{H}+\mathrm{Al}\left(\mathrm{cmol}_{\mathrm{c}} \mathrm{dm}^{-3}\right)\right.$ & 8.94 & 7 & 5.47 \\
$\mathrm{SB}$ & 1.19 & 0.63 & 0.49 \\
$\mathrm{CEC} \mathrm{effective}\left(\mathrm{cmol}_{\mathrm{c}} \mathrm{dm}^{-3}\right)^{2}$ & 2.88 & 2 & 1.51 \\
$\mathrm{CEC} \mathrm{potential}\left(\mathrm{cmol}_{\mathrm{c}} \mathrm{dm}^{-3}\right)^{3}$ & 10.13 & 7.63 & 5.96 \\
$\mathrm{~m}(\%)^{4}$ & 58.68 & 68.5 & 67.55 \\
$\mathrm{~V}(\%)^{5}$ & 11.75 & 8.26 & 8.22 \\
$\mathrm{TOC}\left(\mathrm{g} \mathrm{kg}^{-1}\right)$ & 34.15 & 22.43 & 17.71 \\
$\mathrm{Fe}\left(\mathrm{mg} \mathrm{dm}^{-3}\right)$ & 155.61 & 135.24 & 139.27 \\
$\mathrm{Cu}\left(\mathrm{mg} \mathrm{dm}^{-3}\right)$ & 1.82 & 1.81 & 1.87 \\
$\mathrm{Zn}\left(\mathrm{mg} \mathrm{dm}^{-3}\right)$ & 5.14 & 4.41 & 6.09 \\
$\mathrm{Mn}\left(\mathrm{mg} \mathrm{dm}^{-3}\right)$ & 9.92 & 8.79 & 9.39 \\
$\mathrm{Total} \mathrm{Sand}\left(\mathrm{g} \mathrm{kg}^{-1}\right)$ & 498.2 & 413.7 & 384.1 \\
$\mathrm{Coarse} \mathrm{Sand}\left(\mathrm{g} \mathrm{kg}^{-1}\right)$ & 420.7 & 321.1 & 296.6 \\
Fine Sand $\left(\mathrm{g} \mathrm{kg}^{-1}\right)$ & 77.5 & 92.6 & 87.5 \\
$\mathrm{Silt}\left(\mathrm{g} \mathrm{kg}^{-1}\right)$ & 285.3 & 313.9 & 270.7 \\
$\mathrm{Clay}\left(\mathrm{g} \mathrm{kg}^{-1}\right)$ & 216.5 & 272.4 & 345.2 \\
\hline
\end{tabular}

Note. ${ }^{1}$ Sum of bases; ${ }^{2}$ Effective cation exchange capacity; ${ }^{3}$ Potential cation exchange capacity; ${ }^{4}$ Saturation by aluminum; ${ }^{5}$ Base saturation; ${ }^{6}$ Total organic carbon.

Exchangeable $\mathrm{Ca}^{2+}, \mathrm{Mg}^{2+}$ and $\mathrm{Al}^{3+}$ were extracted with $1.0 \mathrm{~mol} \mathrm{~L}^{-1} \mathrm{KCl}$ and determined by titration. $\mathrm{P}, \mathrm{K}^{+}, \mathrm{Fe}$, $\mathrm{Cu}, \mathrm{Zn}$ and $\mathrm{Mn}$ were extracted by Mehlich-1. Available $\mathrm{P}$ was determined by spectrophotometry, $\mathrm{K}^{+}$by flame photometry, and $\mathrm{Fe}, \mathrm{Cu}, \mathrm{Zn}$ and $\mathrm{Mn}$ by atomic absorption spectrophotometry. Potential acidity $(\mathrm{H}+\mathrm{Al})$ was extracted with $0.5 \mathrm{~mol} \mathrm{~L}^{-1}$ calcium acetate and determined by titration. With these results, sum of bases (SB), base saturation $(\mathrm{V})$, Al saturation $(\mathrm{m})$, effective cation exchange capacity $\left(\mathrm{CEC}_{\text {effective }}\right)$ and potential cation exchange capacity $\left(\mathrm{CEC}_{\text {potential }}\right)$ were all calculated. Physically, the soil was characterized by particle-size distribution, defining its textural class. All analytical procedures were according to P. Teixeira, Donagema, Fondana, and W. Teixeira (2017).

\subsection{Collection of Litter Supply and Analytical Procedures for Nutrients Determination}

Next to each 40 sampling sites used for chemical and physical analysis of the soil, a collector made by nylon net with one-millimeter mesh and $0.25 \mathrm{~m}$ height walls was installed, in a suspended form at approximately $0.50 \mathrm{~m}$ above the ground. The litter supply was evaluated monthly from June 2014 to May 2015.

All material deposited inside the collectors was considered as litter, without fractionation. Its production was quantified from the following equation (Lopes, Domingos, \& Struffaldi-De-Vuono, 2002):

$$
\mathrm{LP}=\left(\sum_{1}^{12} \mathrm{MLP} \times 10,000\right) / \mathrm{CA}
$$

Where, LP is litter production $\left(\mathrm{kg} \mathrm{ha}^{-1} \mathrm{year}^{-1}\right)$; MLP is monthly litter production $\left(\mathrm{kg} \mathrm{ha}^{-1} \mathrm{month}^{-1}\right) ; 10,000$ is a transformation factor of $\mathrm{m}^{2}$ to hectare; $\mathrm{CA}$ is the collector area $\left(\mathrm{m}^{2}\right)$.

Each month, the deposited litter was packed in labeled paper bags and brought to a forced air circulation chamber at $65{ }^{\circ} \mathrm{C}$ until a constant weight was reached. This material was weighed for determination of dry weight, milled, homogenized and packed in previously cleaned and dried vials.

The evaluated nutrients were: N, P, K, Ca and Mg. P, K, Ca and Mg were extracted by nitric-perchloric digestion (Bataglia, Furlani, Teixeira, Furlani, \& Gallo-Júnior, 1983). Ca and Mg were determined by atomic absorption 
spectrophotometry (Teixeira et al., 2017), P was determined by colorimetry (Braga \& Defelipo, 1974), and K determined by flame photometry (Teixeira et al., 2017). $\mathrm{N}$ was extracted by sulfur digestion and determined by distillation and titration by Kjeldahl method (Tedesco, Gianello, Bissani, Bohnen, \& Wolkweiss, 1995).

\subsection{Statistical Procedures}

The data of concentration and contribution of litter and nutrients was statistically processed by analysis of variance. The averages were compared by Scott-Knott test $(\mathrm{P}<0.05)$ when $\mathrm{F}$ test was significant $(\mathrm{P}<0.05)$.

The data of the variables were transformed when the coefficient of variation was greater than $30 \%$. The relationships between climatic factors (rainfall and air temperature) and the contribution of litter and nutrients were evaluated by Pearson correlations ( $r)$. A significant correlation was considered up to $(\mathrm{P}<0.05)$.

\section{Results and Discussion}

\subsection{Litter Deposition}

The annual litter supply was $8,261.15 \mathrm{~kg} \mathrm{ha}^{-1} \mathrm{year}^{-1}$, varying over the months (Figure 3). The litter contribution observed in this study was similar to Machado et al. (2015) that quantified 8,960 $\mathrm{kg} \mathrm{ha}^{-1}$ year $^{-1}$ in a fragment of Atlantic Forest in the middle succession stage in Rio de Janeiro, Brazil. The greatest contribution in forests with more advanced stages of succession may be related to the structural complexity of the vegetation, because changes occur in the composition and diversity of plant species with the progression of the succession (Gough, Curtis, Hardiman, Scheuermann, \& Bond-Lamberty, 2016).

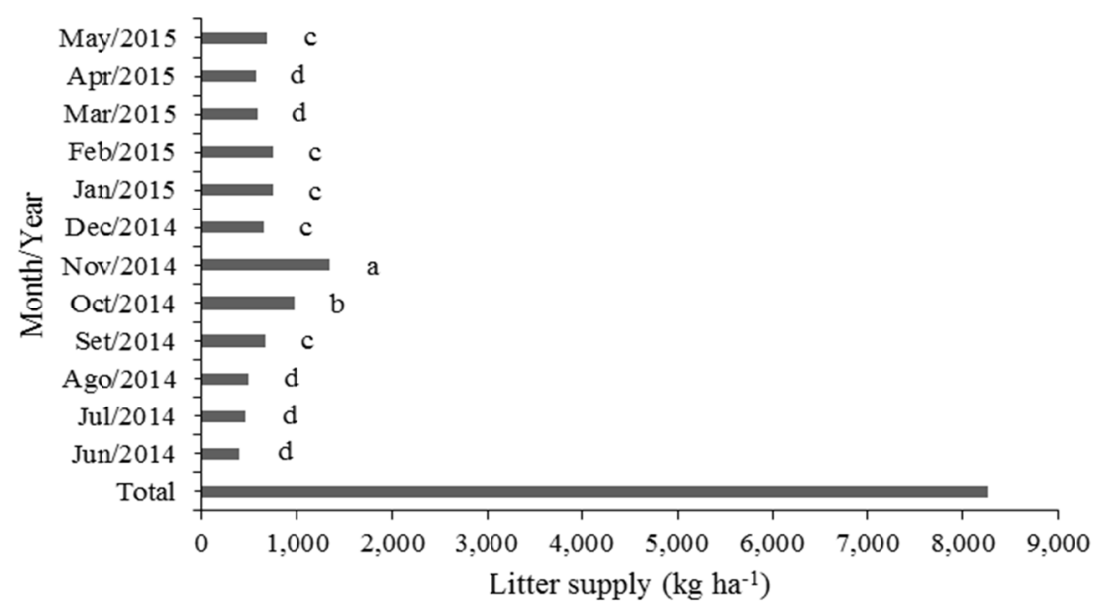

Figure 3. Monthly and annual litter supply in the fragment of Lowland Dense Ombrophilous Forest, Brazil. Averages followed by equal letters do not differ from each other by Scott-Knott test $(\mathrm{P}<0.05)$

Custódio-Filho, Franco, Poggiani, and Dias (1996) studying litter production and nutrient supply in an Atlantic Rain Forest (Dense Ombrophilous Forest) reported annual production of 6,054.10 kg ha-1 year ${ }^{-1}$. Gomes et al. (2010) measured an average contribution of $4,900 \mathrm{~kg} \mathrm{ha}^{-1} \mathrm{year}^{-1}$ in fragments of Atlantic Forest in Rio de Janeiro, Brazil. These contributions were lower than that observed in this study because these fragments were in initial stage of succession.

According to Cunha and Gama-Rodrigues (2014) successional stage of vegetation and soil fertility are factors that cause variations not only in litter supply, but also in all aspects of nutrient cycling in forest ecosystems. Another important factor is the topography, which modifies the nutrient cycling dynamics, due to higher surface runoff observed in forest fragments with high slopes.

Larger litter contributions than those found in this study were quantified by Machado, Piña-Rodrigues, and Pereira (2008), who studied litter production in a secondary forest as a bioindicator of forest recovery in restoration plantation $\left(10,170 \mathrm{~kg} \mathrm{ha}^{-1}\right.$ year $\left.^{-1}\right)$. Espig et al. (2009) reported an annual contribution of $10,070 \mathrm{~kg}$ $\mathrm{ha}^{-1}$ year $^{-1}$, when evaluating the contribution of litter in an Atlantic Forest fragment in Pernambuco, Brazil. Golley, Mcginnis, and Clements (1978) measured a litter supply of $11,350 \mathrm{~kg} \mathrm{ha}^{-1}$ year $^{-1}$ in forest from Panama.

Soil chemical characteristics of the fragment studied by Espig et al. (2009) were similar to this study (Table 1). The soil showed very high acidity, dystrophic soil and high Al saturation. This reinforces the hypothesis that a 
high litter contribution may be directly related to successional stage, because the fragment studied by Espig et al. (2009) was in a more advanced successional stage.

In a review of nutrient cycling in humid tropic ecosystems, Golley et al. (1978) reported that the amount of litter provided in tropical forests worldwide varies between 4,620 and 11,610 kg ha ${ }^{-1}$ year ${ }^{-1}$. Andrade, Caballero, and Faria (1999) reported that in tropical forests on low fertility soils were found 7,500 kg ha-1 $\mathrm{year}^{-1}$ of dry matter in form of litter-forming organic residues, while in medium fertility soils this production was $10,500 \mathrm{~kg} \mathrm{ha}^{-1} \mathrm{year}^{-1}$ and in mountainous areas of $6,300 \mathrm{~kg} \mathrm{ha}^{-1}$ year $^{-1}$.

The highest contributions during the year occurred in dry season, from October/2014 to February/2015 (Figure 3). The highest one was recorded in November 2014 (1,342.39 $\mathrm{kg} \mathrm{ha}^{-1}$ ) (Figure 3). The greatest contribution of litter by the forest during dry season may be a response of vegetation to hydric stress, because leaf fall reduces water loss through transpiration (Bonal, Burban, Stahl, Wagner, \& Hérault, 2016).

Although the greatest contribution of litter occurred in the dry period of the year, there was no observed correlation with rainfall and/or air temperature (Figure 4). Therefore, there was no influence of these climatic factors on litter production during the year. This correlation was also not observed by Lopes, Araújo, and Vasconcellos (2015) in areas of Caatinga from Brazil.
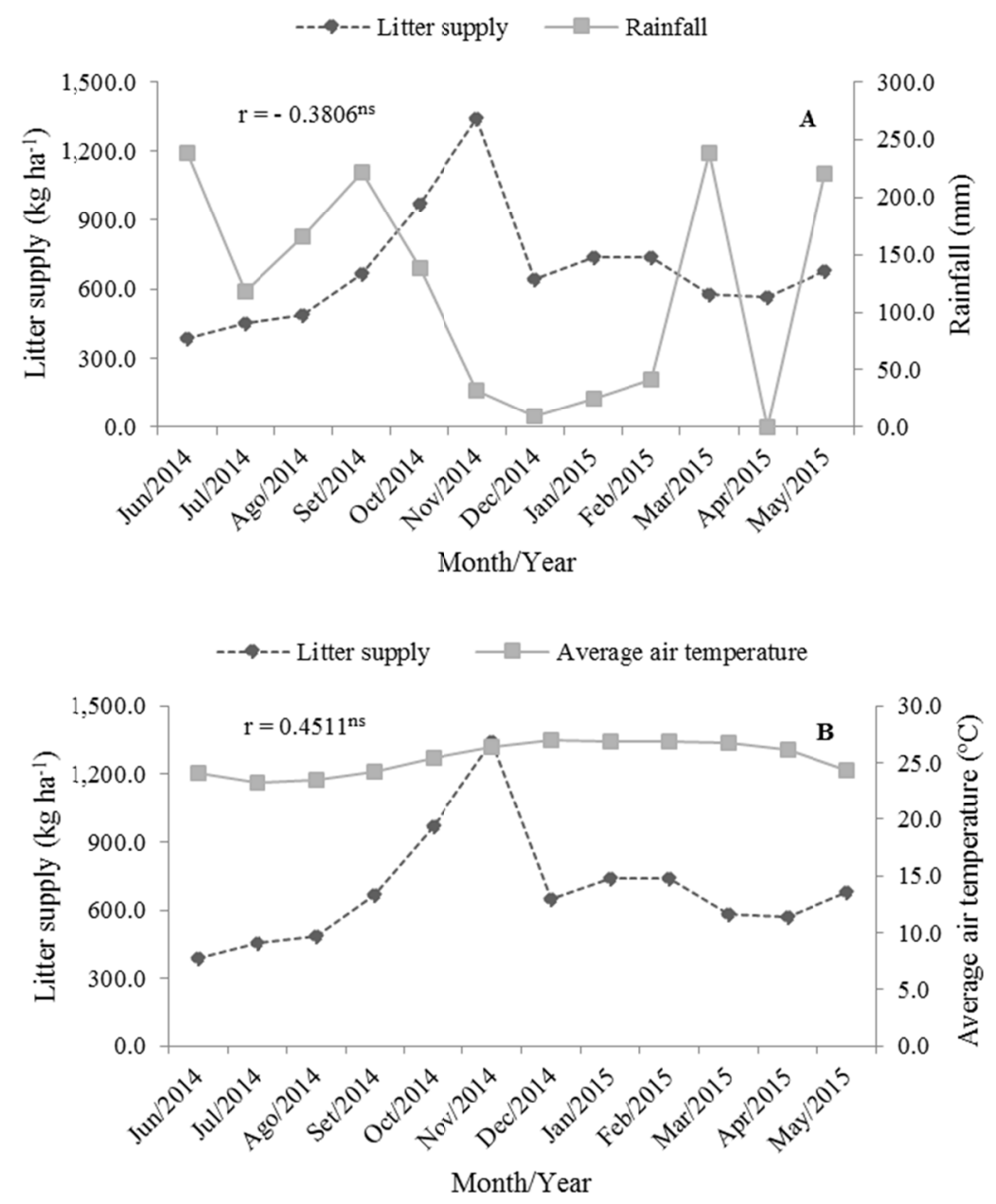

Figure 4. Pearson correlation of litter supply with rainfall (A) and the average air temperature (B) in the fragment of Lowlands Dense Ombrophilous Forest, Brazil. ${ }^{\text {ns }}$ Not significant $(\mathrm{P}<0.05)$

Scoriza and Piña-Rodrigues (2014) reported that some studies confirmed that there was a relationship between contributions of litter to climatic factors, but this correlation could be weak and imprecise. Barlow, Gardner, Ferreira, and Peres (2007) observed that leaf fall in primary and secondary forests was negatively associated with 
rainfall, and was highest in the dry season, when evaluating the relationship between litter production in primary and secondary forests in the Brazilian Amazon.

Espig et al. (2009) found a negative correlation between litter production and rainfall in an Atlantic Forest fragment in Pernambuco, Brazil. The correlation coefficient was low when the authors considered the entire litter deposited $[r=-0.5491(p<0.05)]$ and a little higher $[r=-0.5853(p<0.05)]$, when they considered only leaf deposition.

Rainfall variations throughout the year are very frequent in tropical regions, which can influence the contribution of litter in an inversely proportional way. However, this did not occur because rainfall from June to September 2014 and from March to May 2015 were very variable (Figures 2 and 4), preventing a significant correlation with litter supply.

The air average temperature, especially near oceans, does not vary much (Figure 2) because there is a thermal regulation promoted by the relative humidity of the air coming from the ocean, which makes the contribution of litter not have correlation with this climatic variable (Figure 4).

\subsection{Litter Nutrient Contents}

Nutrient contents provided in the litter corresponded to the following decreasing order: $\mathrm{N}>\mathrm{Ca}>\mathrm{Mg}>\mathrm{K}>\mathrm{P}$ (Table 2). Dickow, Marques, and C. Pinto (2009) also observed this behavior in an area with tree species from secondary rainforests in the South of Brazil.

Table 2. Monthly concentrations and annual average of litter nutrients in the fragment of Lowlands Dense Ombrophilous Forest, Brazil

\begin{tabular}{|c|c|c|c|c|c|}
\hline Month/year & $\mathrm{N}$ & $\mathrm{P}$ & $\mathrm{K}$ & $\mathrm{Ca}$ & $\mathrm{Mg}$ \\
\hline & \multicolumn{5}{|c|}{ 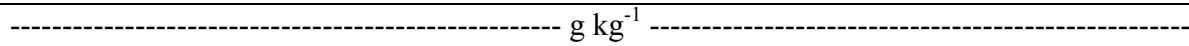 } \\
\hline Jun-14 & $13.09 \mathrm{~b}$ & $0.78 \mathrm{~b}$ & $2.74 \mathrm{a}$ & $8.28 \mathrm{~b}$ & $5.80 \mathrm{c}$ \\
\hline Jul-14 & $14.94 \mathrm{a}$ & $0.82 \mathrm{~b}$ & $1.52 \mathrm{~b}$ & $9.57 \mathrm{~b}$ & $6.00 \mathrm{c}$ \\
\hline Aug-14 & $14.10 \mathrm{a}$ & $0.95 \mathrm{a}$ & $0.91 \mathrm{c}$ & $5.99 \mathrm{c}$ & $6.10 \mathrm{c}$ \\
\hline Sep-14 & $13.78 \mathrm{~b}$ & $0.89 \mathrm{~b}$ & $1.02 \mathrm{c}$ & $7.40 \mathrm{c}$ & $6.50 \mathrm{~b}$ \\
\hline Oct-14 & $12.59 \mathrm{~b}$ & $0.85 \mathrm{~b}$ & $1.10 \mathrm{c}$ & $8.31 \mathrm{~b}$ & $7.10 \mathrm{a}$ \\
\hline Nov-14 & $13.01 \mathrm{~b}$ & $0.95 \mathrm{a}$ & $1.67 \mathrm{~b}$ & $8.16 \mathrm{~b}$ & $7.40 \mathrm{a}$ \\
\hline Dec-14 & $14.67 \mathrm{a}$ & $1.00 \mathrm{a}$ & $1.49 \mathrm{~b}$ & $6.03 \mathrm{c}$ & $4.00 \mathrm{e}$ \\
\hline Jan-15 & $13.66 \mathrm{~b}$ & $1.09 \mathrm{a}$ & $2.78 \mathrm{a}$ & $4.59 \mathrm{c}$ & $3.60 \mathrm{e}$ \\
\hline Feb-15 & $13.74 \mathrm{~b}$ & $1.11 \mathrm{a}$ & $2.53 \mathrm{a}$ & $5.31 \mathrm{c}$ & $3.80 \mathrm{e}$ \\
\hline Mar-15 & $14.44 \mathrm{a}$ & $1.01 \mathrm{a}$ & $1.48 \mathrm{~b}$ & $9.44 \mathrm{~b}$ & $5.09 \mathrm{c}$ \\
\hline Apr-15 & $14.38 \mathrm{a}$ & $1.05 \mathrm{a}$ & $2.29 \mathrm{a}$ & $10.88 \mathrm{a}$ & $4.70 \mathrm{~d}$ \\
\hline May-15 & $14.52 \mathrm{a}$ & $0.85 \mathrm{~b}$ & $1.25 \mathrm{c}$ & $11.18 \mathrm{a}$ & $5.50 \mathrm{c}$ \\
\hline Average & 13.91 & 0.95 & 1.73 & 7.93 & 5.5 \\
\hline $\mathrm{F}_{\text {calculated }}$ & $3.67 * *$ & $5.98 * *$ & $29.65^{* *}$ & $8.09 * *$ & $44.69 * *$ \\
\hline C.V. $(\%)^{1}$ & 17.37 & 29.24 & 22.37 & 31.8 & 21.66 \\
\hline
\end{tabular}

Note. ${ }^{1}$ Coefficient of variation $=100 \times$ standard deviation/average. Averages followed by equal letters in columns do not differ from each other by Scott-Knott test $(\mathrm{P}<0.05)$. ${ }^{* *}$ Significant by test $\mathrm{F}(\mathrm{P}<0.01)$.

Villa, Pereira, Alonso, Beutler, and Leles (2016) observed that $\mathrm{P}$ had the lowest concentration $(\mathrm{N}>\mathrm{Ca}>\mathrm{K}>$ $\mathrm{Mg}>\mathrm{P}$ ) in restoration areas. Pinto, Martins, Barros, and Dias (2009) also observed this same distribution sequence in a semideciduous seasonal forest at the beginning of succession in Viçosa, Minas Gerais, Brazil.

$\mathrm{N}$ contents ranged from 12.59 to $14.94 \mathrm{~g} \mathrm{~kg}^{-1}$, with no significant differences between the months July, August and December 2014, and March, April and May 2015 (higher levels), as well as between June, September, October and November 2014, and lastly January and February 2015 (lower levels) (Table 2).

The $\mathrm{P}$ average content recorded was $0.95 \mathrm{~g} \mathrm{~kg}^{-1}$ (Table 2). This value is higher than that determined by Espig et al. (2009), which was $0.50 \mathrm{~g} \mathrm{~kg}^{-1}$. The authors reported that the fragment presented a more advanced successional stage, which caused $\mathrm{P}$ to be translocated from old leaves to young ones due their mobility. 
The $\mathrm{K}$ average content was $1.73 \mathrm{~g} \mathrm{~kg}^{-1}$ (Table 2). $\mathrm{K}$ content in litter observed in this study was lower than that determined by Espig et al. (2009) in Atlantic Forest area of Pernambuco, Brazil. This may be related to low rates of this nutrient in biogeochemical cycling (Smith et al., 2015). The low K content may also be related to the ease of this nutrient leaching directly from leaf surface by rainwater, due to its high solubility.

Ca presented a mean content of $7.93 \mathrm{~g} \mathrm{~kg}^{-1}$ (Table 2). This high content occurs because $\mathrm{Ca}$ is a structural component found in the cells of the plant tissue, and one of the last nutrients to be released to the soil through litter decomposition (Dickow et al., 2009; Villa et al., 2016). However, this may also be related to the low mobility of $\mathrm{Ca}$ in plant tissues and to the longevity of leaves, which causes it to remain in larger amounts in senescent leaves than other nutrients (Maillard et al., 2015).

$\mathrm{Mg}$ contents presented significant differences between the evaluated months (Table 2). The average content was $5.50 \mathrm{~g} \mathrm{~kg}^{-1}$, higher than those determined by Golley et al. (1978) and Espig et al. (2009), which were $2.04 \mathrm{~g} \mathrm{~kg}^{-1}$ and $2.42 \mathrm{~g} \mathrm{~kg}^{-1}$, respectively. Low content can sometimes be explained by the translocation of this nutrient from senescent leaves to younger ones, decreasing the concentration in the litter (Maillard et al., 2015). The soil of this fragment studied presented high levels of exchangeable $\mathrm{Mg}$ (Table 1), reflecting on nutrition of species and consequently on contribution.

\subsection{Nutrients Supply of Litter}

The annual nutrient contribution from litter to soil presented the following decreasing order: $\mathrm{N}>\mathrm{Ca}>\mathrm{Mg}>\mathrm{K}>$ $\mathrm{P}$ (Table 3). Contribution of $\mathrm{N}$ and $\mathrm{Ca}$ is high in most of the analyzed tropical forests. This happens especially because both occur in larger proportions in leaf component (Lima et al., 2018), which corresponds to most of the litter (Kumar \& Tewari, 2014).

Table 3. Monthly and annual contribution of nutrients from litter in the fragment of Lowlands Dense Ombrophilous Forest, Brazil

\begin{tabular}{|c|c|c|c|c|c|}
\hline Month/year & $\mathrm{N}$ & $\mathrm{P}$ & $\mathrm{K}$ & $\mathrm{Ca}$ & $\mathrm{Mg}$ \\
\hline & \multicolumn{5}{|c|}{ 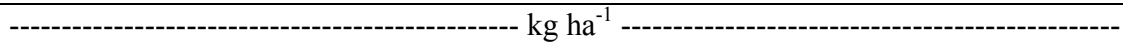 } \\
\hline Jun-14 & $5.09 \mathrm{~g}$ & $0.30 \mathrm{e}$ & $1.07 \mathrm{~b}$ & $3.22 \mathrm{~d}$ & $2.20 \mathrm{e}$ \\
\hline Jul-14 & $6.78 \mathrm{f}$ & $0.37 \mathrm{e}$ & $0.69 \mathrm{c}$ & $4.34 \mathrm{~d}$ & $2.70 \mathrm{e}$ \\
\hline Aug-14 & $6.89 \mathrm{f}$ & $0.46 \mathrm{~d}$ & $0.44 \mathrm{~d}$ & $2.92 \mathrm{~d}$ & $3.00 \mathrm{e}$ \\
\hline Sep-14 & $9.17 \mathrm{~d}$ & $0.59 \mathrm{c}$ & $0.67 \mathrm{c}$ & $4.92 \mathrm{c}$ & $4.30 \mathrm{c}$ \\
\hline Oct-14 & $12.21 \mathrm{~b}$ & $0.83 \mathrm{~b}$ & $1.07 \mathrm{~b}$ & $8.07 \mathrm{~b}$ & $6.80 \mathrm{~b}$ \\
\hline Nov-14 & $17.46 \mathrm{a}$ & $1.27 \mathrm{a}$ & $2.24 \mathrm{a}$ & $10.95 \mathrm{a}$ & $10.00 \mathrm{a}$ \\
\hline Dec-14 & $9.47 \mathrm{~d}$ & $0.65 \mathrm{c}$ & $0.96 \mathrm{~b}$ & $3,89 \mathrm{~d}$ & $2.50 \mathrm{e}$ \\
\hline Jan-15 & $10.11 \mathrm{c}$ & $0.80 \mathrm{~b}$ & $2.06 \mathrm{a}$ & $3.39 \mathrm{~d}$ & $2.60 \mathrm{e}$ \\
\hline Feb-15 & $10.16 \mathrm{c}$ & $0.82 \mathrm{~b}$ & $1.87 \mathrm{a}$ & $3.92 \mathrm{~d}$ & $2.80 \mathrm{e}$ \\
\hline Mar-15 & $8.38 \mathrm{e}$ & $0.59 \mathrm{c}$ & $0.86 \mathrm{c}$ & $5.47 \mathrm{c}$ & $3.40 \mathrm{~d}$ \\
\hline Apr-15 & $8.17 \mathrm{e}$ & $0.59 \mathrm{c}$ & $1.30 \mathrm{~b}$ & $6.17 \mathrm{c}$ & $2.60 \mathrm{e}$ \\
\hline May-15 & $9.86 \mathrm{c}$ & $0.58 \mathrm{c}$ & $0.85 \mathrm{c}$ & $7.59 \mathrm{~b}$ & $3.70 \mathrm{~d}$ \\
\hline Average & 9.48 & 0.66 & 1.17 & 5.41 & 3.9 \\
\hline Total $\left(\mathrm{kg} \mathrm{ha}^{-1}\right.$ year $\left.^{-1}\right)$ & 113.75 & 7.85 & 14.08 & 64.85 & 44.4 \\
\hline $\mathrm{F}_{\text {calculated }}$ & $147.98 * *$ & $62.60 * *$ & $45.53 * *$ & $19.67 * *$ & $233.49 * *$ \\
\hline C.V. $(\%)^{1}$ & 17.22 & 31.15 & 22.73 & 31.59 & 24.16 \\
\hline
\end{tabular}

Note. ${ }^{1}$ Coefficient of variation $=100 \times$ standard deviation/average. Averages followed by equal letters in columns do not differ from each other by Scott-Knott test $(\mathrm{P}<0.05)$. ** Significant by test $\mathrm{F}(\mathrm{P}<0.01)$.

The amount of nutrients contributed to soil was $244.93 \mathrm{~kg} \mathrm{ha}^{-1} \mathrm{year}^{-1}$ (Table 3). $\mathrm{N}$ was the most contributed (46.4\% of annual contribution) and $\mathrm{P}$ the least contributed (3.2\% of annual contribution). Forest nutrition may be dependent on nutrient cycling because the soil of the fragment presented low natural fertility (Table 1). The nutrient cycling may be influenced by climatic variations, both for nutrient supply and for decomposition of the vegetal material.

Aerts (1996) explained that $\mathrm{P}$ is a very mobile element in plant. The translocation occurs from 40 to $60 \%$ of this element located in the older leaves to the younger organs of the plant before foliar abscission. This causes this 
nutrient to be redistributed and used in formation of new tissues. The $\mathrm{P}$ content in this fragment was not low (Table 2) compared to other studies in the same region, such as Espig et al. (2009). However, the migration of $\mathrm{P}$ may have occurred, reducing the contribution.

Correlations between litter nutrient supply and rainfall showed that $\mathrm{N}, \mathrm{P}, \mathrm{Ca}$ and $\mathrm{Mg}$ contributions were not influenced by this climatic variable (Figure 4). However, the correlation between K contributions and rainfall was significant and inverse. The highest $\mathrm{K}$ contributions occurred during the low rainfall period (Figure 5), which is in agreement with results of Espig et al. (2009). This behavior may be due to the ionic form that $\mathrm{K}$ is found in plants (Tripler, Kaushal, Likens, \& Walter, 2006). It can be easily extracted from the tissues by both rainwater and soil moisture, and then lost by leaching (Duchesne, Ouimet, Camiré, \& Houle, 2001).

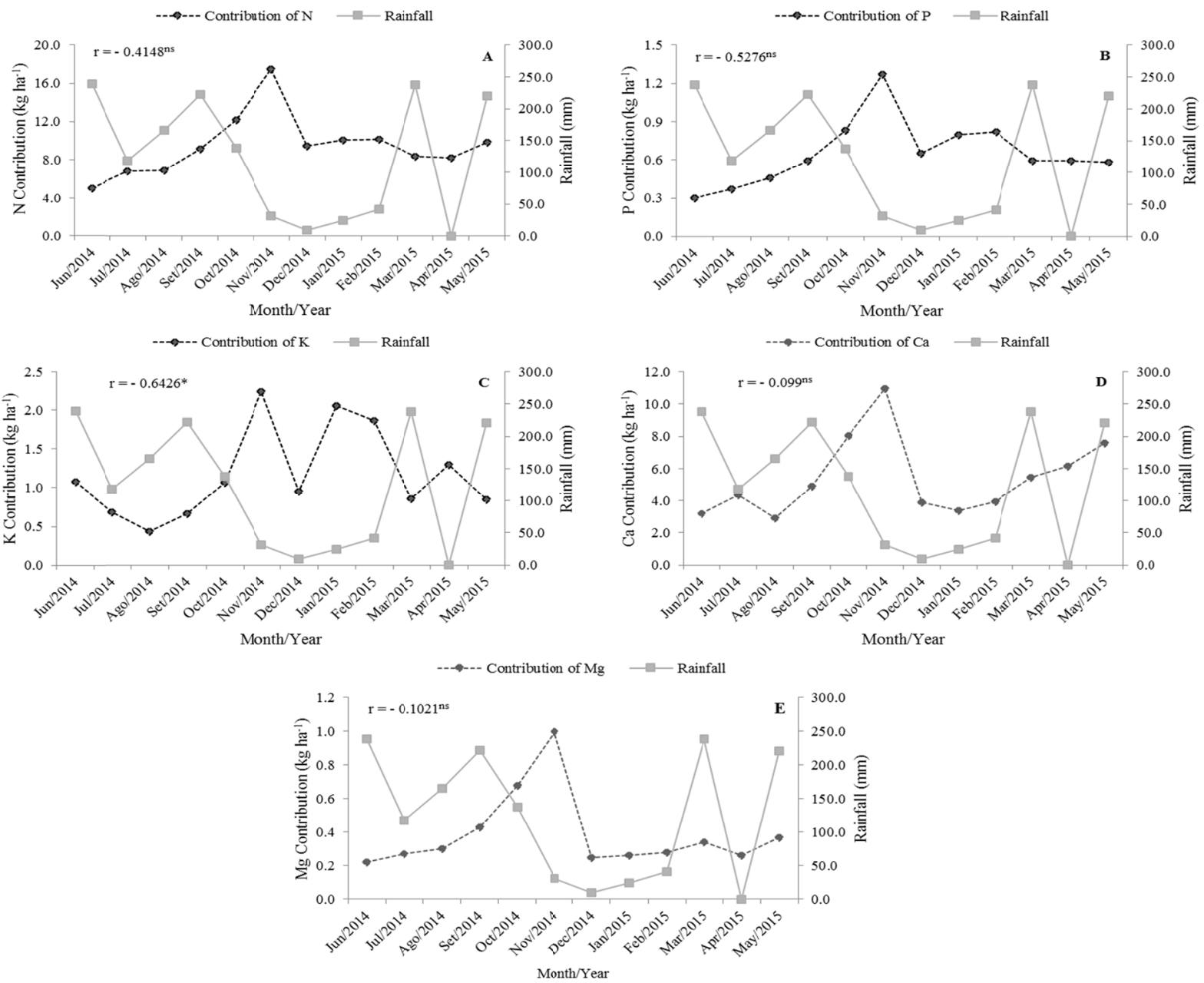

Figure 5. Pearson correlation of the contribution of nitrogen (A), phosphorus (B), potassium (C) calcium (D) and magnesium (E) with rainfall in the remnants of Lowlands Dense Ombrophilous Forest, Brazil. *Significant $(\mathrm{P}<$

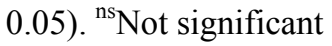

$\mathrm{P}$ and $\mathrm{K}$ contribution correlated with air temperature. The higher contributions occurred during the hotter periods (Figure 6). According to Tripler et al. (2006) and Dickow et al. (2009) the correlations can be attributed to the functions of these nutrients, as well as their dynamics in soil-plant system. Thus, the lowest contributions of this nutrient will may occur during the period of greatest rainfall (Figure 5C). 

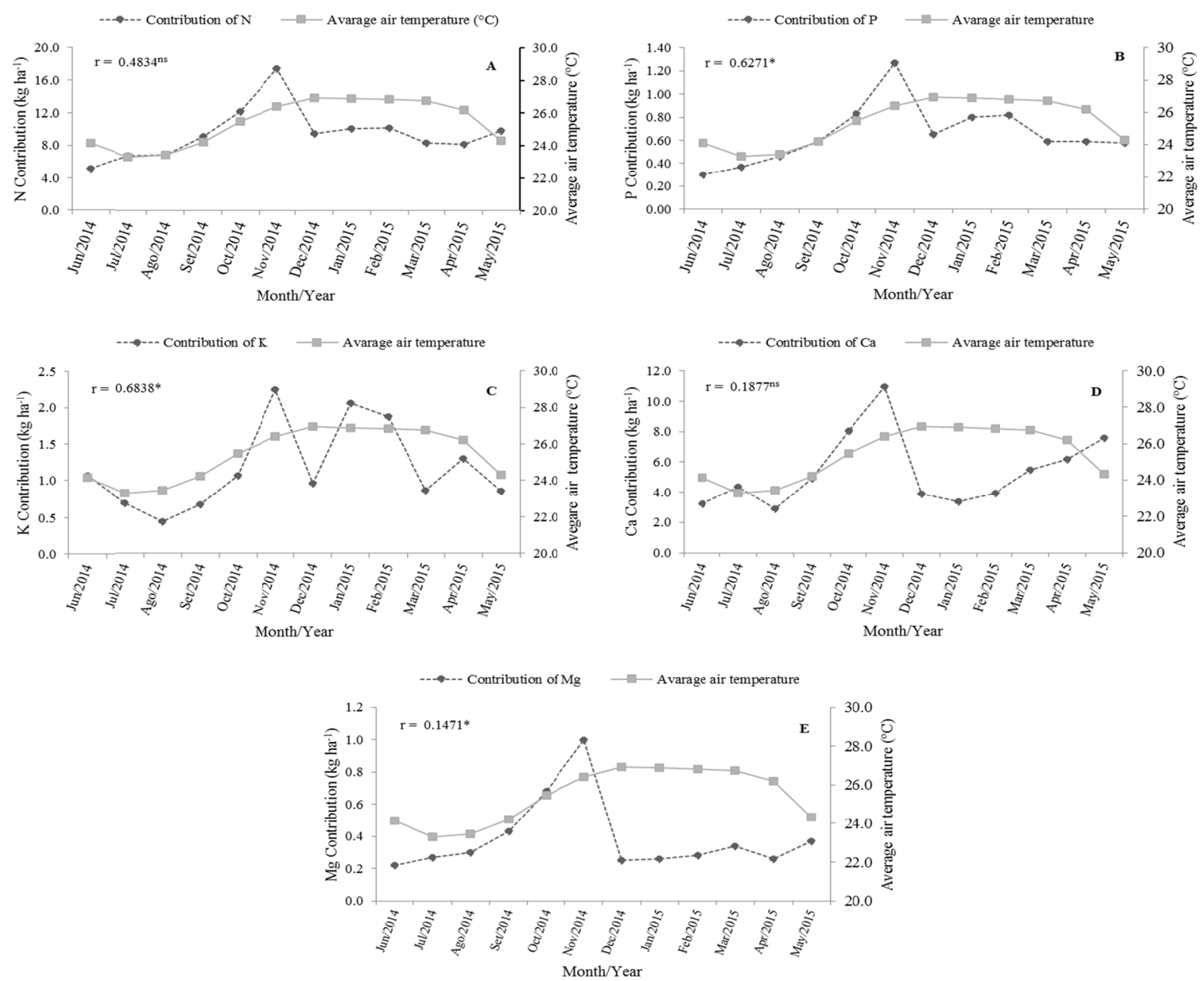

Figure 6. Pearson correlation of the contribution of nitrogen (A), phosphorus (B), potassium (C), calcium (D) and magnesium (E) with the average air temperature in the remnant of Lowlands Dense Ombrophilous Forest,

Brazil. * Significant $(\mathrm{P}<0.05) .{ }^{\mathrm{ns}}$ Not significant

However, higher temperatures are associated with greater contribution because in these periods there is a higher leaf abscission to avoid high levels of transpiration, which reduces water stress caused by adverse conditions, such as high air temperature and low rainfall (Figure 6C).

The $\mathrm{P}$ is a primordial element in plant metabolism, especially in aspects related to acquisition, store and use of energy. Therefore, before the period of foliar abscission begins, this element is translocated to other compartments of plant, such as the stem (Nasto et al., 2017). The correlation between P contribution and rainfall was higher than $52 \%$ (Figure $5 \mathrm{~B}$ ), showing that there is a relation between them, even in small proportions.

$\mathrm{P}$ is not easily leached from the leaf surface by rainfall (Duchesne et al., 2001). Therefore, only higher air temperature is associated with higher contribution because there is no loss of this nutrient due leaching. G. Zhang, P. Zhang, Peng, Chen, and Cao (2017) when evaluating leaf, litter, and soil in warn temperate forests in northwestern China also verified a correlation of $\mathrm{P}$ with air temperature.

Our results showed that litter deposition was $8,261.15 \mathrm{~kg} \mathrm{ha}^{-1}$ year $^{-1}$ and was not influenced by rainfall and temperature. The $\mathrm{N}, \mathrm{P}, \mathrm{K}, \mathrm{Ca}$ and $\mathrm{Mg}$ stock in this litter was $244.93 \mathrm{~kg} \mathrm{ha}^{-1}$ year $^{-1}$, being stored just of $\mathrm{N} 113.75$ $\mathrm{kg} \mathrm{ha}^{-1}$ year $^{-1}$. P and $\mathrm{K}$ stocks varied with rainfall and temperature, suggesting that variations in these climatic variables may interfere in the cycling of these nutrients in this forest fragment.

\section{References}

Aerts R. (1996). Nutrient resorption from senescing leaves of perennial: Are there general patterns. The Journal of Ecology, 84(4), 597-608. https://doi.org/10.2307/2261481 
Alvares, C. A., Stape, J. L., Sentelhas, P. C., Gonçalves, J. L. M., \& Sparovek, G. (2013). Köppen's climate classification map for Brazil. Meteorologische Zeitschrift, 22(6), 711-728. https://doi.org/10.1127/09412948/2013/0507

Andrade, A. G., Caballero, S. S. U., \& Faria, S. M. (1999). Ciclagem de nutrientes em ecossistemas florestais. Rio de Janeiro, RJ: Embrapa.

APAC. (2016). Boletim do clima: Síntese climática. Recife, PE: APAC.

Banegas, N., Albanesi, A., Pedraza, R. O., Santos, D. A. (2015). Non-linear dynamics of litter decomposition under different grazing management regimes. Plant and Soil, 393(1), 1-12. https://doi.org/10.1007/s1110 4-015-2472-y

Barlow, J., Gardner, T. A., Ferreira, L. V., \& Peres, C. A. (2007). Litter fall and decomposition in primary, secondary and plantation forests in the Brazilian Amazon. Forest, Ecology and Management, 247(1-3), 91-97. https://doi.org/10.1016/j.foreco.2007.04.017

Bataglia O. C., Furlani, O. C., Teixeira, A. M. C., Furlani, J. P. F., \& Gallo-Júnior, P. R. (1983). Métodos de análise química de plantas. São Paulo, SP: Instituto Agronômico de Campinas.

Bonal, D., Burban, B., Stahl, C., Wagner, F., \& Héralt, B. (2016). The response of tropical rainforests to drought-Lessons from recent research and future prospects. Annals of Forest Science, 73(1), 27-44. https://doi.org/10.1007/s13595-015-0522-5

Braga, J. M., \& Defelipo, B. V. (1974). Determinação espectrofotométrica de fósforo em extrato de solo e material vegetal. Revista Ceres, 21(113), 73-85.

Cavalcanti, E. P., Silva, V. P. R., Sousa, \& F. A. S. (2006). Programa computacional para a estimativa da temperatura do ar para a região Nordeste do Brasil. Revista Brasileira de Engenharia Agrícola e Ambiental, 10(1), 140-147. https://doi.org/10.1590/S1415-43662006000100021

Cunha, G. M., \& Gama-Rodrigues, A. C. (2014). Does nutrient cycling differ between fragments of Atlantic Forest with distinct structural aspects? A case study in the state of Rio de Janeiro, Brazil. Acta Botanica Brasilica, 28(4), 609-616. https://doi.org/10.1590/0102-33062014abb3525

Custódio-Filho, A., Franco, G., Poggiani, F., \& Dias, A. C. (1996). Produção de serapilheira e o retorno de macronutrientes em floresta pluvial atlântica—Estação Biológica de Boracéia (São Paulo-Brasil). Revista dp Instituto Florestal, 8(1), 1-16.

Dickow, K. M. C., Marques, R., \& Pinto, C. B. (2009). Nutrient composition of mature and litter leaves and nutrient mobilization in leaves of tree species from secondary rainforests in the South of Brazil. Brazilian Archives of Biology and Technology, 52(5), 1099-1106. https://doi.org/10.1590/S1516-89132009000 500006

Diniz, A. R., Machado, D. L., Pereira, M. G., Balieiro, F. C., \& Menezes, C. E. G. (2015). Biomassa, estoque de carbono e de nutrientes em estádios sucessionais da floresta atlântica, RJ. Revista Brasileira de Ciências Agrárias, 10(3), 443-451.

Duchesne, L., Ouimet, R., Camiré, C., \& Houle, D. (2001). Seasonal nutrient transfers by foliar resorption, leaching, and litter fall in a northern hardwood forest at Lake Clair Watershed, Quebec, Canada. Canadian Journal of Forest Research, 31(2), 333-344. https://doi.org/10.1139/x00-183

Espig, S. A., Freire, F. J., Marangon, L. C., Ferreira, R. L. C., Freire, M. B. G. S., \& Espig, D. B. (2009). Sazonalidade, composição e aporte de nutrientes da serapilheira em fragmento de Mata Atlântica. Revista Árvore, 33(5), 949-956. https://doi.org/10.1590/S0100-67622009000500017

Ferreira, M. L., Silva, J. L., Pereira, E. E., \& Lamano-Ferreira, A. P. N. (2014). Litter fall production and decomposition in a fragment of secondary Atlantic Forest of São Paulo, SP, southeastern Brazil. Revista Árvore, 38(4), 591-600. https://doi.org/10.1590/S0100-67622014000400002

Golley, F. B., Mcginnis, J. T., \& Clements, R. G. (1978). Ciclagem de minerais em um ecossistema de floresta tropical úmida. São Paulo, SP: EPU-EDUSP.

Gomes, J. M., Pereira, M. G., Piña-Rodrigues, F. C. M., Pereira, G. H. A., Gondim, F. R., \& Silva, E. M. R. (2010). Aporte de serapilheira e de nutrientes em fragmentos florestais da Mata Atlântica, RJ. Revista Brasileira de Ciências Agrárias, 5(3), 383-391. https://doi.org/10.5039/agraria.v5i3a552 
Gough, C. M., Curtis, P. S., Hardiman, B. S., Scheuermann, C. M., \& Bond-Lamberty, B. (2016). Disturbance, complexity, and succession of net ecosystem production in North America's temperate deciduous forests. Ecosphere, 7(6), e01375. https://doi.org/10.1002/ecs2.1375

Jacoby, R., Peukert, M., Succurro, A., Koprivova, A., \& Kopriva, S. (2017). The role of soil microorganisms in plant mineral nutrition-Current knowledge and future directions. Frontiers in Plant Science, 8, 1617. https://doi.org/10.3389/fpls.2017.01617

Kumar, S., \& Tewari, L. M. (2014). Pattern of litter fall and litter decomposition in a Quercus leucotrichophora A. Camus forest in Kumaun Himalaya. International Journal of Biodiversity and Conservation, 6(1), 108-114. https://doi.org/10.5897/IJBC2013.0617

Leff, J. W., Wieder, W. R., Taylor, P. G., Townsend, A. R., Nemergut, D. R., Grandy, A. S., \& Cleveland, C. C. (2012). Experimental litterfall manipulation drives large and rapid changes in soil carbon cycling in a wet tropical forest. Global Change Biology, 18(9), 2969-2979. https://doi.org/10.1111/j.1365-2486.2012.02749.x

Lima, R. B. A., Freire, F. J., Marangon, L. C., Feliciano, A. L. P., Silva, R. K. S., Freire, M. B. G. S., \& Freire, C. S. (2018). Nutritional efficiency of plants as an indicator of forest species for the restoration of forests, Brazil. Scientia Forestalis, 46(119), 415-426. https://doi.org/10.18671/scifor.v46n119.09

Li, X., Niu, J., \& Xie, B. (2014). The effect of leaf litter cover on surface runoff and soil erosion in Northern China. PLoS ONE, 9(9), e107789. https://doi.org/10.1371/journal.pone.0107789

Llausàs, A., \& Nogué, J. (2012). Indicators of landscape fragmentation: The case for combining ecological indices and the perceptive approach. Ecological Indicators, 15(1), 85-91. https://doi.org/10.1016/j.ecolin d.2011.08.016

Lopes, M. C. A., Araújo, V. F. P., \& Vasconcellos, A. (2015). The effects of rainfall and vegetation on litterfall production in the semiarid region of northeastern Brazil. Brazilian Journal of Biology, 75(3), 703-708. https://doi.org/10.1590/1519-6984.21613

Lopes, M. I. S., Domingos, M., \& Struffaldi-De-Vuono, Y. (2002). Ciclagem de nutrientes minerais. In L. Syslvestre, \& M. M. T. Rosa (Eds.), Manual metodológico para estudos botânicos na Mata Atlântica (pp. 72-102). Seropédica, RJ: EDUR-UFRRJ.

Machado, D. L., Pereira, M. G., Correia, M. E. F., Diniz, A. R., Santos, L. L., \& Menezes, C. E. G. (2015). Ciclagem de nutrientes em diferentes estádios sucessionais da Mata Atlântica na bacia do rio Paraíba do Sul, RJ. Bioscience Journal, 31(4), 1222-1237. https://doi.org/10.14393/BJ-v31n1a2015-23092

Machado, M. R., Piña-Rodrigues, F. C. M., \& Pereira, M. G. (2008). Produção de serapilheira como bioindicador de recuperação em plantio adensado de revegetação. Revista Árvore, 32(1), $143-151$. https://doi.org/10.159 0/S0100-67622008000100016

Maillard, A., Diquélou, S., Billard, V., Laine, P., Garnica, M, Prudent, M., Garcia-Mina, J., ... Ourry, A. (2015). Leaf mineral nutrient remobilization during leaf senescence and modulation by nutrient deficiency. Frontier in Plant Science, 6, 317. https://doi.org/10.3389/fpls.2015.00317

Martins, L., \& Cavararo, R. (2012). Manual Técnico da Vegetação Brasileira. Brasília, DF: IBGE.

Nasto, M. K., Osborne, B. B., Lekberg, Y., Asner, G. P., Balzotti, C. S., Porder, S., Taylor, P. G., ... Cleveland, C. C. (2017). Nutrient acquisition, soil phosphorus partitioning and competition among trees in a lowland tropical rain forest. New Phytologist, 214, 1506-1517. https://doi.org/10.1111/nph.14494

Pinto, S. I. C., Martins, S. V., Barros, N. F., \& Dias, H. C. T. (2009). Ciclagem de nutrientes em dois trechos de Floresta Estacional semidecidual na reserva florestal Mata do Paraíso em Viçosa, MG, Brasil. Revista Árvore, 33(4), 653-663. https://doi.org/10.1590/S0100-67622009000400008

Santos, H. G., Jacomine, P. K. T., Anjos, L. H. C., Oliveira, V. A., Lumbreras, J. F., Coelho, M. R., Almeida, J. A., ... Oliveira, J. B. (2013). Sistema Brasileiro de Classificação de Solos. Brasília, DF: Embrapa.

Scoriza, R. N., \& Piña-Rodrigues, F. C. M. (2014). Influência da precipitação e temperatura do ar na produção de serapilheira em trecho de Floresta Estacional em Sorocaba, SP. Floresta, 44(4), 4687-696. https://doi.org/10.5380/rf.v44i4.34274

Silva, P. H. M., Poggiani, F., Lima, W. P., \& Libardi, P. L. (2014). Soil water dynamics and litter production in eucalypt and native vegetation in southeastern Brazil. Scientia Agricola, 71(5), 345-355. https://doi.org/ 10.1590/0103-9016-2013-0325 
Smith, P., Cotrufo, M. F., Rumpel, C., Paustian, K., Kuikman, P. J., Elliott, J. A., McDowell, R., ... Scholes, M. C. (2015). Biogeochemical cycles and biodiversity as key drivers of ecosystem services provided by soils. Soil, 1, 665-685. https://doi.org/10.5194/soil-1-665-2015

Soil Survey Staff. (2014). Keys to soil taxonomy. Washington, DC: Soil Conservation Service.

Tedesco, M. J., Gianello, C., Bissani, C. A., Bohnen, H., \& Wolkweiss, S. J. (1995). Análises de solo, plantas e outros materiais. Porto Alegre, RS: Universidade Federal do Rio Grande do Sul.

Teixeira, P. C., Donagema, G. K., Fondana, A., \& Teixeira, W. G. (2017). Manual de métodos de análise de solo. Rio de Janeiro, RJ: Embrapa.

Tripler, C. E., Kaushal, S. S., Likens, G. E., \& Walter, M. T. (2006). Patterns in potassium dynamics in forest ecosystems. Ecology Letters, 9, 451-466. https://doi.org/10.1111/j.1461-0248.2006.00891.x

Villa, E. B., Pereira, M. G, Alonso, J. M., Beutler, S. J., \& Leles, P. S. S. (2016). Aporte de serapilheira e nutrientes em área de restauração florestal com diferentes espaçamentos de plantio. Floresta e Ambiente, 23(1), 90-99. https://doi.org/10.1590/2179-8087.067513

Wood, T. E., Lawrence, D., Clark, D. A., \& Chazdon, R. L. (2009). Rain forest nutrient cycling and productivity in response to large-scale litter manipulation. Ecology, 90(1), 109-121. https://doi.org/10.1890/07-1146.1

Xiaogai, Ge., Lixiong, Z., Wenfa, X., Zhilin, H., Xiansheng, G., \& Benwang, T. (2013). Effect of litter substrate quality and soil nutrients on forest litter decomposition: A review. Acta Ecologica Sinica, 33(2), 103-108.

Zhang, G., Zhang, P., Peng, S., Chen, Y., \& Cao, Y. (2017). The coupling of leaf, litter, and soil nutrients in warm temperate forests in northwestern China. Scientific Reports, 7, 11754. https://doi.org/10.1038/ s41598-017-12199-5

\section{Copyrights}

Copyright for this article is retained by the author(s), with first publication rights granted to the journal.

This is an open-access article distributed under the terms and conditions of the Creative Commons Attribution license (http://creativecommons.org/licenses/by/4.0/). 